\title{
Using the Graphite Isotope Ratio Method to Verify the DPRK's Plutonium-Production Declaration
}

\section{Jungmin Kang}

\author{
Independent Nuclear Analyst, McLean, VA, USA
}

The graphite isotope ratio method can give an accurate estimate of the total plutonium production in a graphite-moderated reactor without detailed information on the reactor's operating history. Transmutation of trace impurities in the graphite is directly related to the cumulative plutonium production in the nuclear fuel. This study explains how the total amount of plutonium produced in the five megawatt electric graphite reactor at Yongbyon could be estimated using the Graphite Isotope Ratio Method (GIRM) technique once a number of strategically located samples from the graphite moderator are available.

\section{INTRODUCTION}

On 26 June 2008, the Democratic People's Republic of Korea (DPRK) submitted a declaration of its plutonium-production activities to China. According to Glenn Kessler of the Washington Post, it declared that it possessed 37 kilograms of plutonium. ${ }^{1}$ According to Global Security Newswire, however, the DPRK declared that it had extracted 30.8 kilograms of plutonium from spent nuclear fuel using its reprocessing facility and had used 2 kilograms of that amount in its October 2006 nuclear test. ${ }^{2}$ In addition to the controversy over the amount of separated plutonium, the DPRK had unseparated plutonium in the 8,000 spent fuel rods in the cooling pond at Yongbyon before April 2009.

The Graphite Isotope Ratio Method (GIRM) can be used to estimate the total plutonium production in a graphite-moderated reactor without detailed

Received 24 June 2009; accepted 11 March 2011.

The author would like to thank Alexander Glaser and Zia Mian at Princeton University for their very useful comments.

Address correspondence to Jungmin Kang, 1350 Beverly Rd., Apt. 811, McLean, VA 22101, USA. E-mail: jungminkang64@gmail.com 
information on the reactor's operating history. The basic idea of GIRM is that the transmutation of trace impurities in the graphite is directly related to the cumulative plutonium production in the nuclear fuel. ${ }^{3}$

This study explains how the total amount of plutonium produced in the 5-megawatt electric (MWe) graphite reactor at Yongbyon (hereafter the 5MWe reactor) could be estimated using the GIRM technique.

\title{
GRAPHITE ISOTOPE RATIO METHOD
}

GIRM was originally proposed by Steve Fetter. In his 1993 Science \& Global Security paper, Fetter pointed out that:

\begin{abstract}
A small fraction of the neutrons produced by fission will be absorbed in the moderator and permanent structural components of the reactor core, usually producing radioactive nuclei. If these radioactive nuclei have long half-lives (much longer than the lifetime of the reactor), very little radioactive decay will occur, and the concentration of these nuclei will be proportional to the total number of neutrons passing through the material (the neutron "fluence"). Thus, long-lived radionuclides produced by neutron absorption in naturally occurring nuclei in the permanent components of the reactor core provide an estimate of the neutron fluence at that point. When coupled with reasonable assumptions about the design and operation of the reactor, measurements of neutron-induced radionuclides at several points in the core can be used to estimate neutron fluences and plutonium production. ${ }^{4}$
\end{abstract}

The Pacific Northwest National Laboratory (PNNL) developed the GIRM concept into a practical plutonium production verification tool for graphitemoderated reactors in the early $1990 \mathrm{~s} .{ }^{5}$ When tested on the Hanford plutonium-production reactors, it was found that GIRM does indeed provide an accurate estimate of lifetime plutonium production of a graphite moderated reactor.

The first step in GIRM is to identify suitable indicator elements that exist in graphite in sufficient concentrations to be accurately measured. According to a PNNL report, the $\mathrm{B}^{10} / \mathrm{B}^{11}$ ratio is an excellent indicator element for low-fluence reactors, while $\mathrm{Ti}^{48} / \mathrm{Ti}^{49}$ has been successfully used for highfluence reactors. ${ }^{6}$ This study focuses on the $\mathrm{B}^{10} / \mathrm{B}^{11}$ ratio. Boron-10 and Boron11 are both stable isotopes, constituting 19.9 and 80.1 percent of natural boron respectively.

The second step of GIRM is sampling a reactor's irradiated graphite and measuring the post-irradiation ratio of the targeted isotopes. ${ }^{7}$ To maximize the accuracy of the total plutonium production estimate, the number of samples and their locations must be optimized. Until graphite samples are available from the 5 MWe reactor, calculated $\mathrm{B}^{10} / \mathrm{B}^{11}$ ratios of graphite samples must be used to demonstrate the method. 
The third step of the GIRM is to estimate from the isotope ratios cumulative plutonium production values in the fuel at locations near where the graphite samples were taken. This study uses the MCNPX $\left.^{\circledR}\right)$ Monte Carlo radiation transport depletion computer code to make this correlation. ${ }^{8}$

The final step is to estimate cumulative plutonium production for the entire core using a regression technique, based on the estimated cumulative plutonium production values near the sample locations. The regression technique produces a three dimensional map that closely fits the local cumulative plutonium production values. This study uses Wolfram Mathematica $7^{\mathbb{R}}$ as the regression tool. ${ }^{9}$

\section{THE 5 MWe REACTOR}

\section{Core Characteristics}

The 5 MWe reactor is a graphite-moderated reactor fueled by naturaluranium metal clad in Magnox magnesium alloy. ${ }^{10}$ The fuel rods are placed in channels in the graphite moderator, and are cooled by $\mathrm{CO}_{2}$ gas flowing through the channels. Table 1 shows the characteristics of the 5 MWe reactor. A horizontal cross-section of the reactor is shown in Figure $1 .^{11}$

\section{Operating History}

The 5 MWe reactor operated from 1985 until April 1994 and from February 2003 to July $2007 .^{12}$

Table 1: Estimated Physical Characteristics of the $5 \mathrm{MWe}$ Reactor $^{\mathrm{i}}$

\begin{tabular}{|c|c|c|c|}
\hline \multicolumn{4}{|c|}{ Physical characteristics of the $5 \mathrm{MWe}$ reactor } \\
\hline Thermal power & 25 MWth & Effective core radius & $643 \mathrm{~cm}$ \\
\hline Electric power & $5 \mathrm{MWe}$ & Effective core height & $592 \mathrm{~cm}$ \\
\hline Specific power & $0.50 \mathrm{MWth} / \mathrm{tHM}$ & Upper reflector & $77.50 \mathrm{~cm}$ \\
\hline Úranium loaded & $50 \dagger$ & Bottom reflector & $66.50 \mathrm{~cm}$ \\
\hline Graphite-moderator & $300 \dagger$ & Fuel composition & U (0.5\%Al) \\
\hline Graphite-reflector & $300 \dagger$ & Diameter of fuel meat & $2.90 \mathrm{~cm}$ \\
\hline Number of channels & $812-877$ & Length of fuel meat & $52 \mathrm{~cm}$ \\
\hline Number of fuel channels & 801 & Length of fuel rod & $60 \mathrm{~cm}$ \\
\hline $\begin{array}{l}\text { Number of control rod } \\
\text { channels }\end{array}$ & 44 & Uranium per fuel rod & $6.24 \mathrm{~kg}$ \\
\hline $\begin{array}{l}\text { Number of fuel rods per } \\
\text { channel }\end{array}$ & 10 & Clad composition & $\operatorname{Mg}(1 \% A l)$ \\
\hline $\begin{array}{l}\text { Distance between } \\
\text { channels }\end{array}$ & $20 \mathrm{~cm}$ & Clad thickness & $0.05 \mathrm{~cm}$ \\
\hline Radius of channel & $6.50 \mathrm{~cm}$ & & \\
\hline
\end{tabular}

'David Albright and Kevin O'Neill, eds., op. cit., 161.B.D. Murphy, "ORIGEN-ARP Cross-Section Libraries for Magnox, Advanced Gas-Cooled, and VVER Reactor Designs," Oak Ridge National Laboratory, ORNL/TM-2003/263(2004). Personal communication with KAERI, November 2008. 


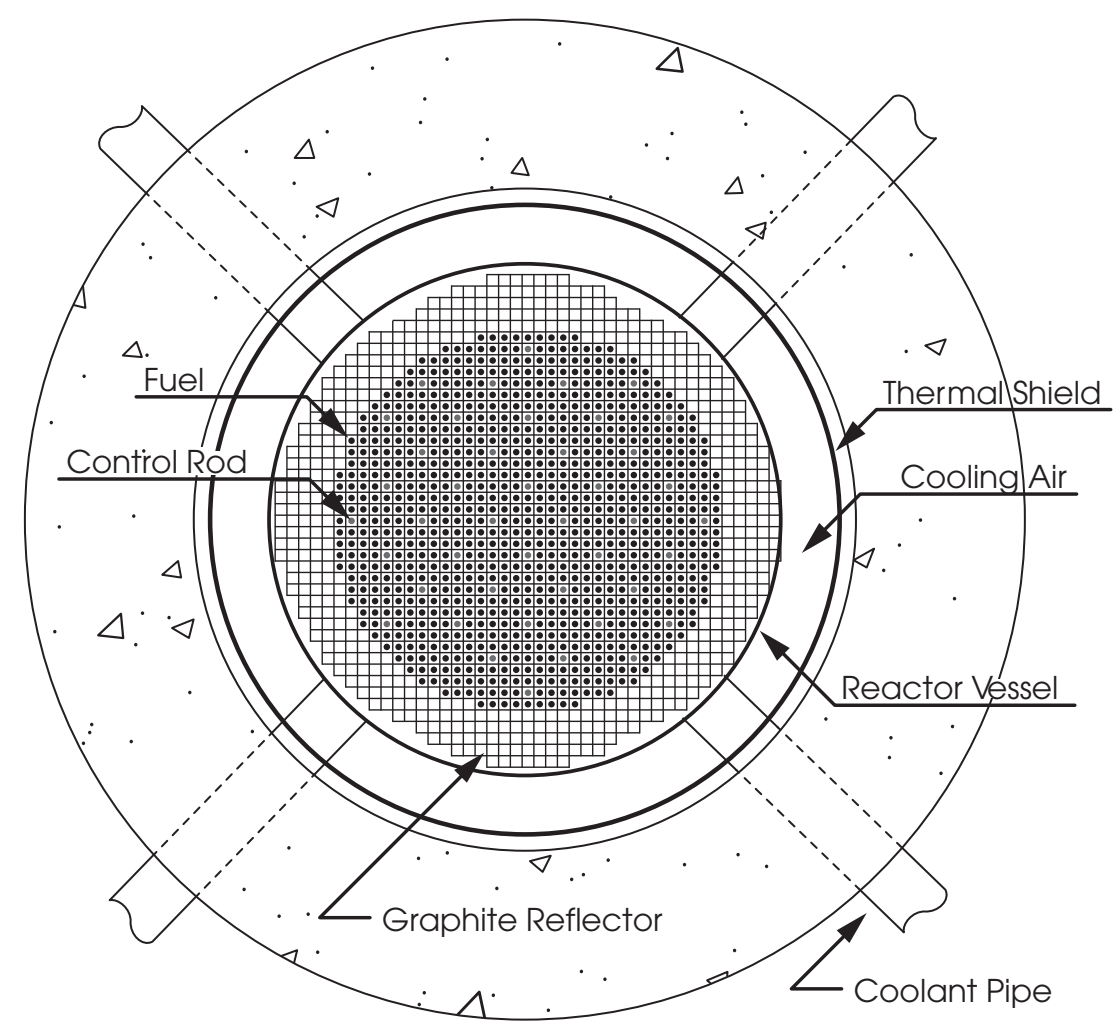

Figure 1: Cross-section of the $5 \mathrm{MWe}$ reactor. Source: KAERI.

The reactor was shut down in 1994, in accordance with the US-DPRK Agreed Framework, until the Framework's breakdown in December 2002. The DPRK resumed operation of the reactor in February 2003 and then shut it down again in mid-July 2007 to disable it in accordance with the 13 February 2007 Agreement of the Six-Party Talks. The reactor was stopped between April and June 2005 for discharge of fuel for reprocessing. ${ }^{13}$ On 14 April 2009, after the U.N. Security Council condemned the DPRK's April 5 test of a long-range ballistic missile, the DPRK announced that it would restore the 5 MWe reactor to operation. ${ }^{14}$ However, as of Spring 2011, it had not done so.

The average burnup of the irradiated fuel in the 5 MWe reactor in 1994 is estimated to have been about 600-700 MWd/tHM. ${ }^{15}$ If the fuel had not been discharged and reprocessed, even after an additional four years of full power operation of the reactor between February 2003 and July 2007, its average burnup would still have been only about $1,100 \mathrm{MWd} / \mathrm{tHM}$, assuming a capacity factor of 70 percent. ${ }^{16}$ That burnup is assumed in following calculations. 


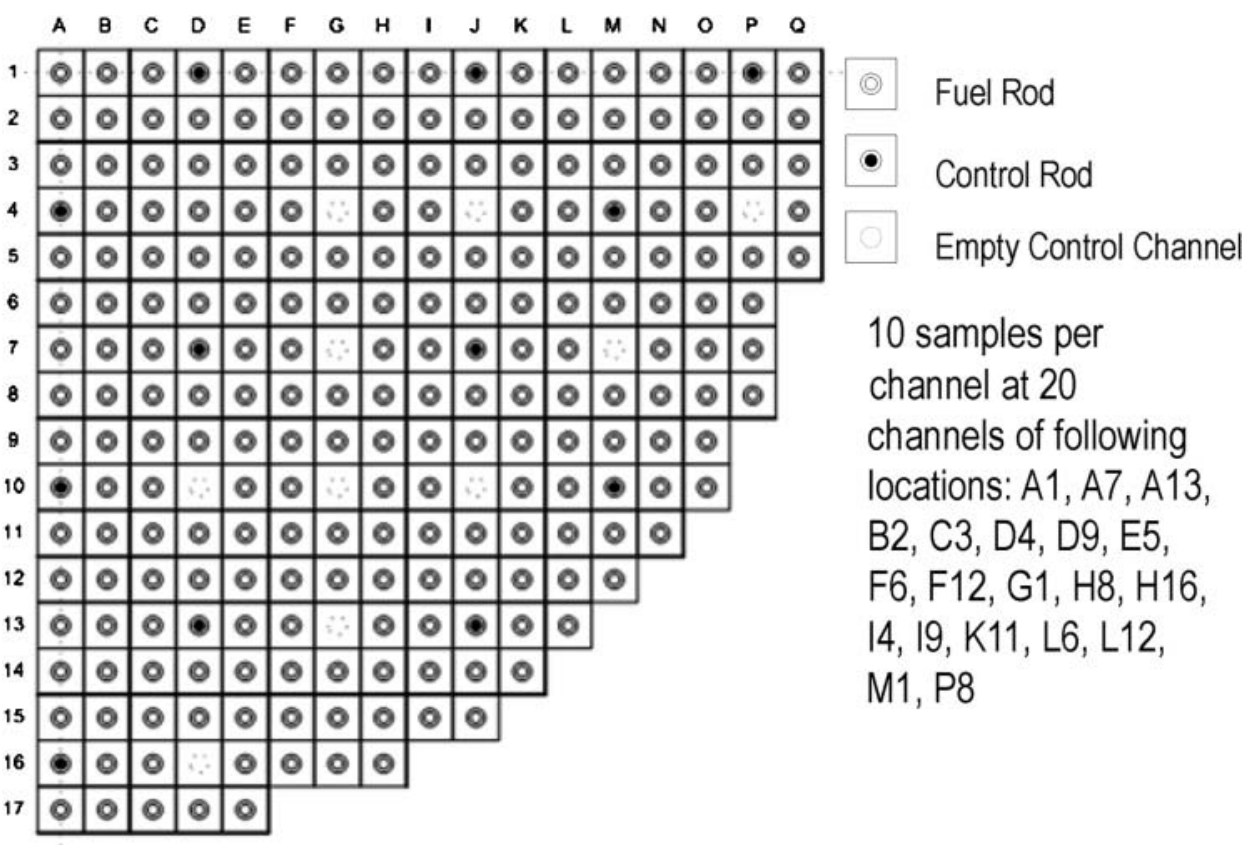

Figure 2: $1 / 4$ core layout of the $5 \mathrm{MWe}$ reactor and sampling locations. Source: KAERI.

\section{SIMULATING BORON ISOTOPIC RATIOS}

Since the core is symmetric, it would be necessary to take samples in one angular sector. We assume that graphite samples would be taken at 200 locations of a $1 / 4$ core as shown in Figure 2 . Simulated $B^{10} / B^{11}$ ratios of graphite samples just outside the aluminum channel liners are given in Table $2 .{ }^{17}$

Table 2: Simulated $\mathrm{B}^{10} / \mathrm{B}^{11}$ ratios of graphite samples at $\mathrm{A} 1$ location of Figure 2 


\section{Kang}

\section{LOCAL CUMULATIVE PLUTONIUM PRODUCTION ESTIMATES}

Based on the physical characteristics shown in Table 1, the cross-section of a three dimensional cell-model of the fuel, channel liner and graphite surrounding a fuel channel is given in Figure 3. Neutron reflecting boundary conditions are assumed. This is equivalent to approximating the core as infinite.

Using the geometry of the pin-cell model and the material specifications in Table 1 , the calculated $\mathrm{B}^{10} / \mathrm{B}^{11}$ ratio as a function of cumulative plutonium production per $\mathrm{cm}^{3}$ of fuel are given in Figure 4 .

Using the MCNPX ${ }^{\mathbb{R}}$ code results given in Figure 4 , the simulated $\mathrm{B}^{10} / \mathrm{B}^{11}$ ratios of graphite samples, that are assumed to be taken for analysis at 200 locations in the $1 / 4$ core of the 5 MWe reactor, are correlated to the local cumulative plutonium production of fuel rods located adjacent to the sample locations. $^{18}$

\section{ESTIMATE OF THE TOTAL CUMULATIVE PLUTONIUM PRODUCTION}

The local cumulative plutonium production values are used to fix the parameters of a fitting function that depends upon the vertical and radial position in the core to estimate total cumulative plutonium production throughout the core of the $5 \mathrm{MWe}$ reactor. The regression technique is calculated with Mathematica $7^{\mathbb{R}} .^{19}$

The resulting estimate based on the pin-model-derived correlation in Figure 4 is $42.84 \mathrm{~kg}$, which differs by 1.1 percent from an estimate of $42.39 \mathrm{~kg}$ obtained by the same independent 1/4-core model depletion burnup calculation that produced the simulated boron isotopic ratios for an average fuel burnup of $1,100 \mathrm{MWd} / \mathrm{tHM}{ }^{20}$

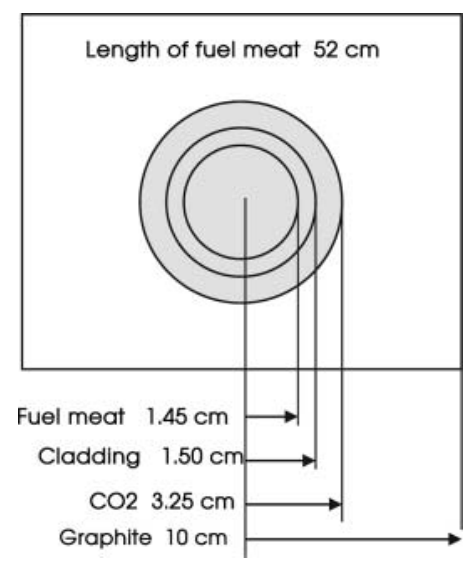

Figure 3: Three-dimensional pin-cell model of a fuel rod of the $5 \mathrm{MWe}$ reactor (with reflecting boundary conditions). 


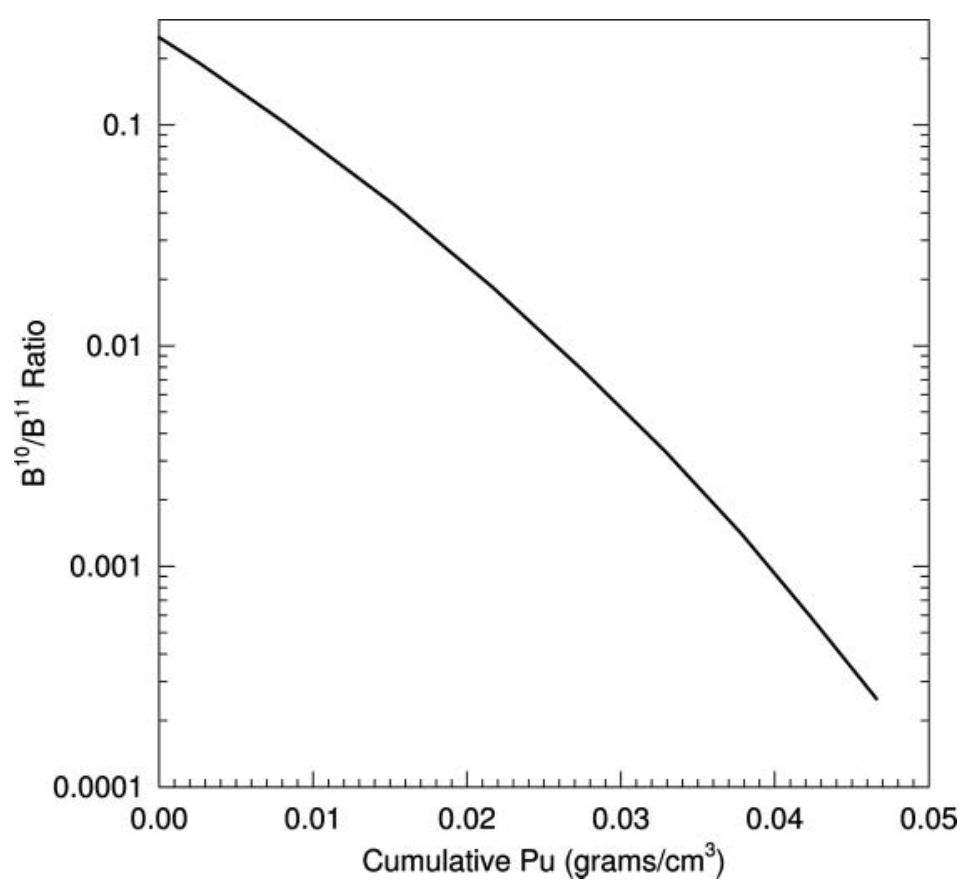

Figure 4: $\mathrm{B}^{10} / \mathrm{B}^{11}$ ratio as a function of cumulative plutonium production (grams $/ \mathrm{cm}^{3}$ ) on the three dimensional pin-cell model of a fuel rod of the $5 \mathrm{MWe}$ reactor.

\section{CONCLUSIONS}

Using GIRM, the cumulative plutonium production of the 5 MWe graphite reactor of the DPRK can be accurately estimated without operational history, once a number of strategically located graphite samples are available.

\section{NOTES AND REFERENCES}

1. Glenn Kessler, "Message to U.S. Preceded Nuclear Declaration by North Korea," The Washington Post, 2 July 2008, A7. The DPRK's declaration did not include information on its nuclear-weapon and uranium enrichment activities.

2. Nuclear Threat Initiative (NTI), "North Korea Declares 31 Kilograms of Plutonium," Global Security Newswire, 24 October 2008; According to Selig S. Harrison who visited Pyongyang in early January 2009, the DPRK said that it has weaponized almost 31 kilograms of plutonium. Choe Sang-Hun, "North Korea Says It Has 'Weaponized' Plutonium," New York Times, 18 January 2009, A8.

3. C. J. Gesh, "A Graphite Isotope Ratio Method Primer-A Method for Estimating Plutonium Production in Graphite Moderated Reactors," PNNL-14568, Pacific Northwest National Laboratory (February 2004). 
4. Steve Fetter, "Nuclear Archaeology: Verifying Declarations of Fissile-Material Production," Science \& Global Security 3 (1993): 237-259.

5. Thomas W. Wood, Matthew D. Milazzo, Barbara A. Reichmuth, and Jeffrey Bedell, "Establishing Confident Accounting for Russian Weapons Plutonium," The Nonproliferation Review (Summer 2002): 126-137. B.D. Reid et al., "Graphite Isotope Ratio Method Development Report: Irradiation Test Demonstration of Uranium as a Low Fluence Indicator," PNNL-13056, Pacific Northwest National Laboratory (September 1999).

6. C. J. Gesh, op. cit.

7. Graphite samples of about 1-cm in diameter and 2-cm in length can be extracted from any location in the core by commercially available automated graphite reactor sampling machines. For the measurement of key isotopic ratios in the samples, mass-spectrometry measurement techniques are used. Secondary ionization mass spectrometry is used to analyze boron isotopic ratios, while thermal ionization mass spectrometry is used to analyze titanium, uranium and plutonium ratios. C. J. Gesh, op. cit.

8. MCNPX $^{\circledR}$ (MCNP eXtended) is a Monte Carlo radiation transport computer code that transports nearly all particles at nearly all energies and performs depletion calculations of nuclear fuels. John S. Hendricks et al., "MCNPX ${ }^{\circledR}$ 2.6.0 Extensions," Los Alamos National Laboratory, LA-UR-08-2216 (April 2008).

9. Wolfram Mathematica $7^{\circledR}<$ http://www.wolfram.com/products/mathematica/index. html $>$.

10. The 50 MWe British Calder Hall reactor is believed to have been the model of the 5 MWe reactor. David Albright and Kevin O'Neill, eds., Solving the North Korean Nuclear Puzzle (Washington, DC: The Institute for Science and International Security, 2000), p. 146.

11. Personal communication with the Korean Atomic Energy Research Institute (KAERI), November 2008.

12. David Albright and Kevin O'Neill, eds., op. cit., 119.

13. For additional information on the Yongbyon Nuclear Scientific Research Center see for example, <http://en.wikipedia.org/wiki/Yongbyon_Nuclear_Scientific_Research_ Center $>$.

14. The DPRK announced that it would restore the nuclear fuel fabrication facility and the reprocessing facility. "Timeline of North Korea's Nuclear, Missile Programs," Fox News, 25 April 2009 http://www.foxnews.com/story/0,2933,517880,00.html.

15. David Albright and Kevin O’Neill, eds., op. cit., 118.

16. The accumulated core average burnups of the 5-MWe reactor between February 2003 and April 2005 and between June 2005 and mid-July 2007 are about 220 $\mathrm{MWd} / \mathrm{tHM}$ and $210 \mathrm{MWd} / \mathrm{tHM}$, respectively, assuming $20 \mathrm{MW}$ thermal power and a capacity factor of 70 percent.

17. Based on the $1 / 4$ core model of the 5 MWe reactor containing spent fuel with average burnup of $1,100 \mathrm{MWd} / \mathrm{tHM}$, the simulated $\mathrm{B}^{10} / \mathrm{B}^{11}$ ratios of graphite samples were calculated by an expert at KAERI using a three dimensional Monte Carlo burnup code, developed by Seoul National University and KAERI. The calculations assume all control rods are out from their channels. Personal communication from KAERI, June 2009 .

18. To calculate the expected cumulative plutonium production $\left(\mathrm{grams} / \mathrm{cm}^{3}\right)$ for any given $\mathrm{B}^{10} / \mathrm{B}^{11}$ value, the following equation is used to fit the curve in Figure 4 using 
Wolfram Mathematica ${ }^{\circledR}: \mathrm{Pu}\left(\right.$ milligrams $\left./ \mathrm{cm}^{3}\right)=-13.2-23.3 \mathrm{x}-1.87 \mathrm{x}^{-2}$, where $\mathrm{x}=$ $\log \left(\mathrm{B}^{10} / \mathrm{B}^{11}\right)$.

19. Wolfram Mathematica $7^{\circledR}$. Functional form of the fitting function in this study is $\mathrm{F}(\mathrm{x}, \mathrm{y}, \mathrm{z})=0.0307848-1.74155 \times 10^{-7} \mathrm{x}^{2}-1.75037 \times 10^{-7} \mathrm{y}^{2}-5.13598 \times 10^{-7} \mathrm{z}-$ $1.83897 \times 10^{-7} \mathrm{z}^{2}$.

20. Personal communication with KAERI, June 2009. 